\title{
The 9 September 2010 torrential rain and flash flood in the Dragone catchment, Atrani, Amalfi Coast (southern Italy)
}

\author{
C. Violante ${ }^{1}$, G. Braca ${ }^{2}$, E. Esposito ${ }^{1}$, and G. Tranfaglia ${ }^{2}$ \\ ${ }^{1}$ Istituto per l'Ambiente Marino Costiero (IAMC), Consiglio Nazionale delle Ricerche (CNR), Naples, Italy \\ ${ }^{2}$ Istituto Superiore per la Protezione e la Ricerca Ambientale (ISPRA), Rome, Italy \\ Correspondence to: C. Violante (crescenzo.violante@cnr.it)
}

Received: 22 June 2015 - Published in Nat. Hazards Earth Syst. Sci. Discuss.: 12 August 2015

Revised: 14 January 2016 - Accepted: 20 January 2016 - Published: 4 February 2016

\begin{abstract}
In this paper we use a multi-hazard approach to analyse the 9 September 2010 flash flood in the Dragone basin, a $9 \mathrm{~km}^{2}$ catchment located along the Amalfi rocky coastal range, southern Italy. In this area, alluvial fan flooding has been the most frequent and destructive geologic hazard since Roman times. Sudden torrents of water (flash floods) are caused by high-intensity and very localized cloudbursts of short duration, inducing slope erosion and sediment delivery from slope to stream. The elevated bed load transport produces fast-moving hyperconcentrated flows with significant catastrophic implications for communities living at the stream mouth.

The 9 September 2010 rainstorm event lasted $1 \mathrm{~h}$ with an intensity rainfall peak of nearly $120 \mathrm{~mm} \mathrm{~h}^{-1}$. High topographic relief of the Amalfi coastal range and positive anomalies of the coastal waters conditioned the character of the convective system. Based on geological data and post-event field evidence and surveys, as well as homemade videos and eyewitness accounts, it is reported that the flash flood mobilized some $25000 \mathrm{~m}^{3}$ of materials with a total (water and sediment) peak flow of $80 \mathrm{~m}^{3} \mathrm{~s}^{-1}$. The estimated peak discharge of only clear water was about $65 \mathrm{~m}^{3} \mathrm{~s}^{-1}$. This leads to a sediment bulking factor of 1.2 that corresponds to a flow with velocities similar to those of water during a flood.
\end{abstract}

\section{Introduction}

The Amalfi Coast consists of a steep mountain front (up to $1444 \mathrm{~m}$ a.s.l.) that rises abruptly from the Tyrrhenian Sea (Fig. 1). It is a rocky coast mostly formed by a pile of Mesozoic carbonate rocks, covered by Tertiary to Quater- nary siliciclastic and pyroclastic units which have been tectonically uplifted since the lower Pleistocene. Bedrock rivers and channels deeply dissect the carbonate bedrock, forming a complex fluvial system characterized by small catchments that are very high relative to the base sea level. These rivers show a distinct seasonality and torrential behaviour, with main delivery areas into the adjacent marine shelf (Fig. 2; Esposito et al., 2004; Budillon et al., 2005; Violante, 2009; Violante et al., 2009).

During the last millennia this area has been repeatedly mantled by the pyroclastic products of the Somma-Vesuvio that create favourable conditions for volcaniclastic debris to generate rainfall-triggered mass flows and flash floods. The Plinian eruption, that destroyed the Roman cities of Pompeii, Stabiae and Herculaneum in AD 79, deposited up to $2 \mathrm{~m}$ of erosion-prone volcaniclastic material (Sigurdsson et al., 1985) on the steep coastal slopes, causing conditions of increased geomorphic instability.

Geologic evidences for rapid slope erosion following the Pompeii pyroclastic fall include alluvial reworked volcaniclastic sequences (locally called Durece) occurring as residual outcrops along narrow stream valleys (Cinque and Robustelli, 2009) and coastal fan deltas fed by small alluvial fans at the mouth of the main streams (Sacchi et al., 2009; Violante et al., 2009). The latter are composed of wedge-shaped coarse-grained alluvial deposits that thicken towards the sea and represent the subaqueous counterpart of small fans at the river mouths (Fig. 2, inset).

Pyroclastic air-fall tephra derived from the late Quaternary activity of Somma-Vesuvio still represent unstable sedimentary covers on top of the steep carbonate slopes of the Amalfi Coast. These deposits create conditions of elevated 


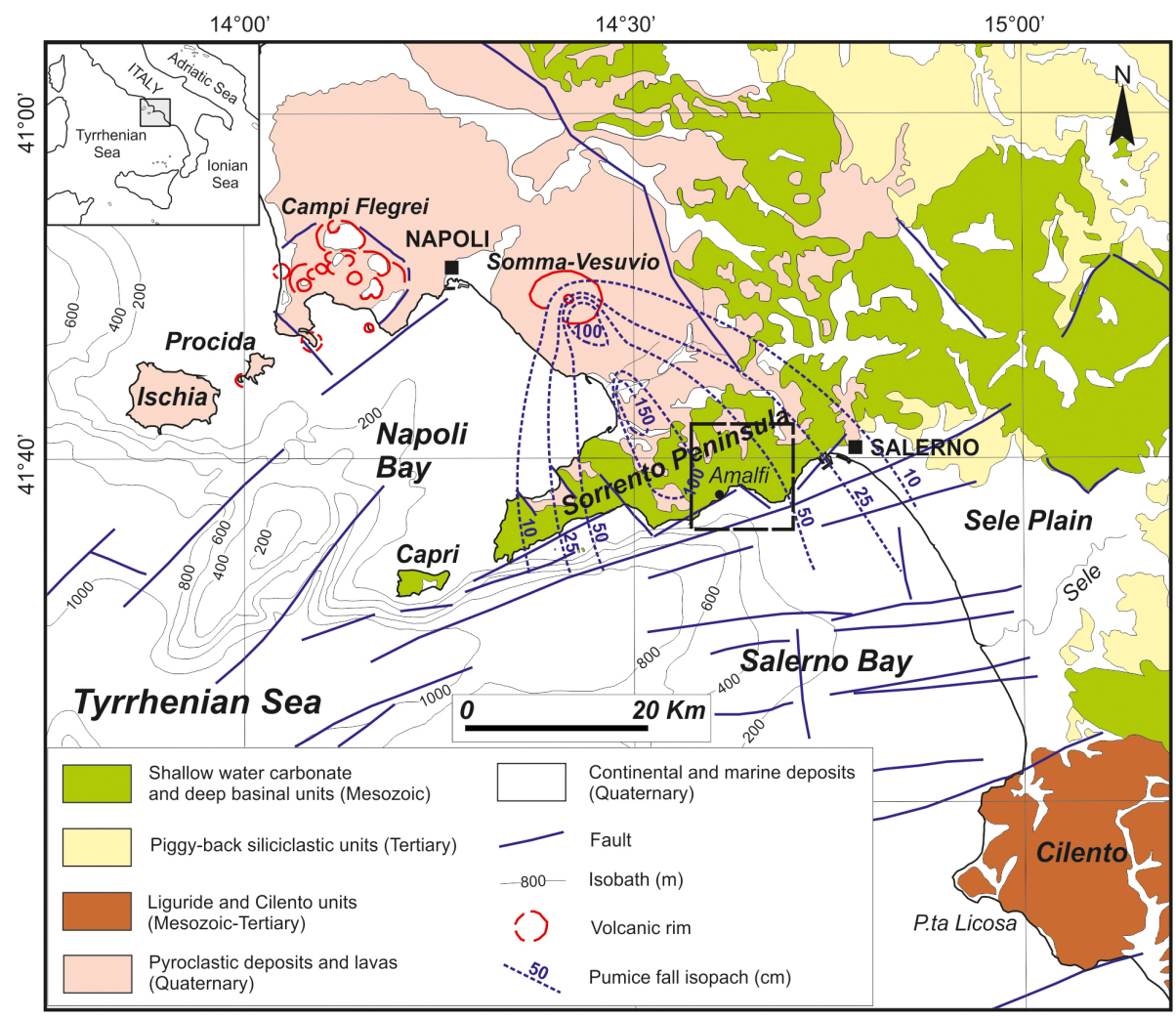

Figure 1. Geological sketch map and location of the study area (dashed box).

slope instability in conjunction with rainstorm events that frequently hit the Amalfi Coast. The slides are mostly shallow and very wide, extending all the way to the mountain ridge and crest, and largely belong to the categories of soil slip and debris/earth flow phenomena. In addition to rapid sediment transport along the valley flanks, landslide debris flowing from slope to streams produces fast-moving large debris torrents (flash floods) with significant catastrophic implications for local communities mostly living on alluvial fans at stream mouths. Here flood-prone streams have been artificially forced to flow underneath roads and squares to exploit the whole delta surfaces for urban development (Fig. 2).

Human interference plays an important role in the generation of flood hazard (e.g. Smith and Ward, 1998; Plate, 2002). In particular, the mismanagement and lack of maintenance of channel sections and the deforestation of water catchment areas can significantly increase the risk of flash floods. In the study area, extensive terracing through deforestation and use of rocks to build retaining walls has generated a cultural landscape strictly depending on the correct management of mountain slopes and channel beds. Interference by human actions has been documented for past floods in the SarnoQuindici area (Calcaterra et al., 2003), located a few kilometres north of Atrani, which was hit by a destructive flooding event in 1998.
In this paper we analyse the 9 September 2010 rainfall event that hit the Amalfi Coast and its effects on the Dragone catchment and the village of Atrani. Direct field observations that include geological investigations and damage to property and infrastructures have been combined with meteorological and hydraulic/hydrological analyses. Reconstruction and recurrence of past events based on different historical sources and marine geophysical and geological data of the Dragone submerged delta have also been taken into account.

\section{The Dragone catchment fan delta system}

The Dragone catchment drains an area of $9.3 \mathrm{~km}^{2}$ along the steep coastal slopes of the Amalfi Coast. The basin develops in a north-south direction and is strongly asymmetric, with the eastern flank composed of a short and abrupt slope corresponding to a fault scarp and the western flank formed by four main sub-basins: Scalandrone, Nocelle, Senite, and S. Caterina. A fifth sub-basin, Frezzi, develops at the head of the Dragone stream (Fig. 3a). The drainage area rises up to $1420 \mathrm{~m}$ a.s.l. and cuts into Mesozoic limestone discontinuously mantled by Quaternary volcaniclastic and alluvial deposits. A low drainage frequency $\left(5 \mathrm{~km}^{-2}\right)$ and a subdendritic pattern characterize the hydrographic network with the main stream, the Dragone, discharging directly into the Tyrrhenian Sea. Slope analysis based on a $5 \times 5 \mathrm{~m}$ cell size 


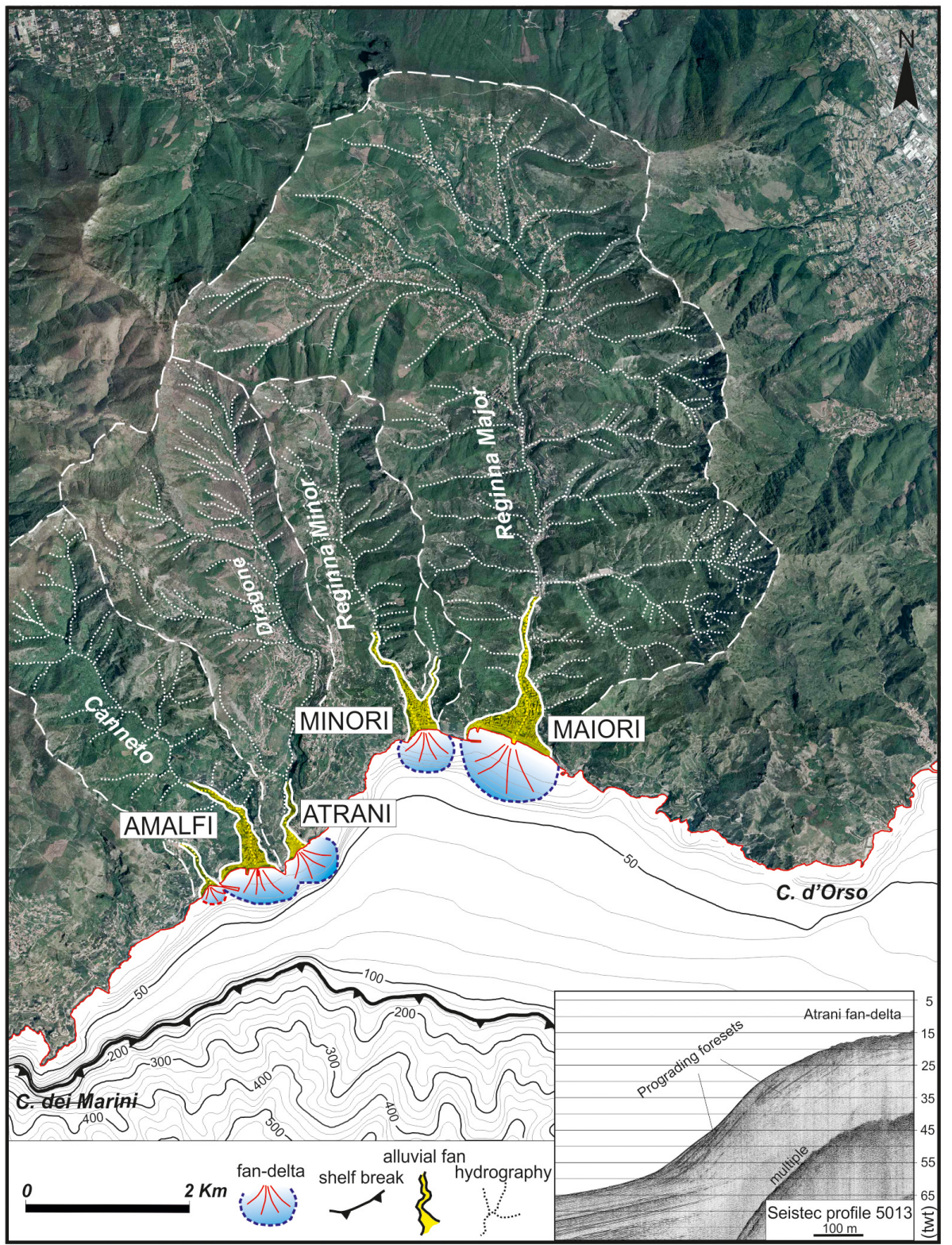

Figure 2. The Amalfi rocky coast system characterized by steep and high watersheds, urbanized alluvial fans and fan deltas at the mouth of main streams, reduced continental shelf engraved by canyons, and abrupt shelf break (fault-controlled). The fan deltas are composed of prograding clinoforms resulting from flood activity as revealed by the high-resolution seismic profiles (inset map in the lower right corner). Modified after Violante (2009) and Sacchi et al. (2009).

DTM (digital elevation model) indicates that the topographic gradient of the catchment area is arranged into two main slope classes, ranging from 15 to $35^{\circ}$ and from 35 to $50^{\circ}$ (golden/yellow and brown colours, respectively, in Fig. 3b). The mean slope is $30^{\circ}$.

The Dragone stream is $6.8 \mathrm{~km}$ in length with the terminal section covered by a roadway crossing the village of Atrani. The covered section of the water course has an input section of $3 \times 9 \mathrm{~m}(h \times w)$ that reduces to $1.80 \times 5.50 \mathrm{~m}$ at the closing section, and has a total length of about $300 \mathrm{~m}$. Runoff waters are regulated by concrete levees and check dams that extend over two-thirds of the hydrographic network.

At sea a submerged fan delta is present at the closing section of the Dragone catchment (Sacchi et al., 2009; Violante et al., 2009). The delta body is $0.2 \mathrm{~km}^{2}$ wide and reaches a maximum thickness of $25 \mathrm{~m}$. It displays a generally conical morphology with a delta front slope of $30^{\circ}$ and foreset inclination ranging from 15 to $30^{\circ}$. This structure is composed of alluvial sequences that coincide with significant changes in the river activity during streamflow phenomena. 


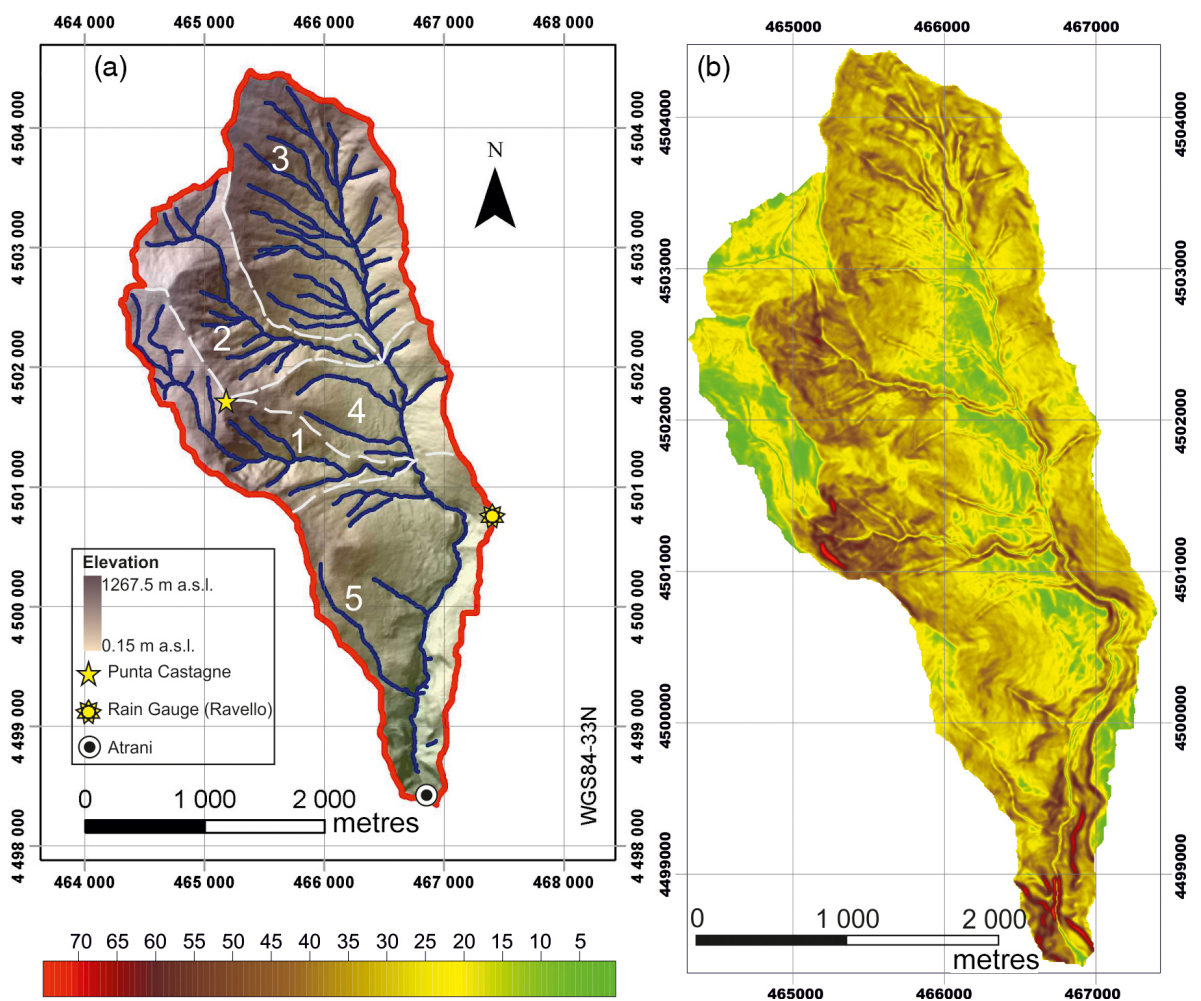

Figure 3. The Dragone catchment. (a) Basin elevation (DEM) and sub-basins of the Dragone stream. 1. Scalandrone, 2. Nocelle, 3. Frezzi, 4. Senite, 5. S. Caterina. (b) Slope map. The scale for the slope map is in the left lower corner.

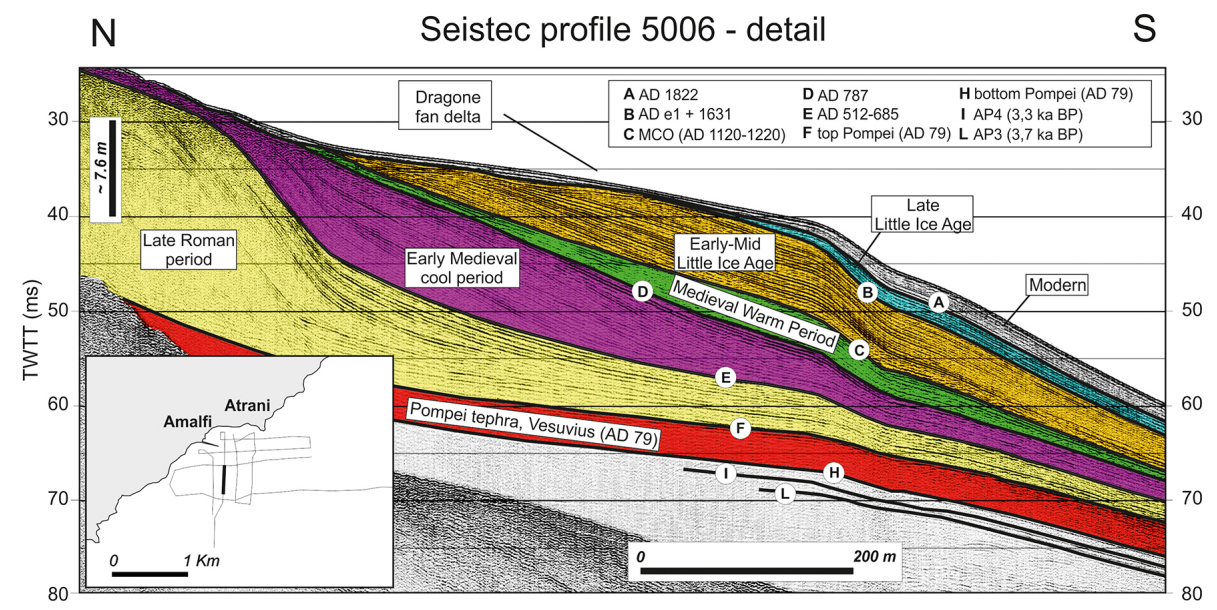

Figure 4. The Dragone-Canneto fan delta body found off the village of Atrani. Detail of a very high-resolution seismic profile showing flood-controlled seismic-stratigraphic units and their inferred association with major climatic changes of the last 2000 years. Letters A to L represent age-dated stratigraphic horizons. See inset map for location (modified after Sacchi et al., 2009).

Increases in fluvial sedimentary discharge are recorded as successive phases of delta growths with which temporary shoreline progradations are associated.

The detailed study of the internal stratigraphic architecture of the Dragone fan delta indicates various depositional phases following the main AD 79 alluvial crisis, possibly modulated by the interplay between the availability of loose pyroclastic covers and the varying erosional rates due to the climatic oscillations occurring in the last millennia (Fig. 4; Sacchi et al., 2009; Violante et al., 2009). The major change detectable in the Amalfi fan deltas occurred in the Early Medieval Cool Period (ca. AD 500-AD 800), that developed immediately after the Roman Warm Period. Further changes in the stratal patterns of the delta foresets, indicative of high 

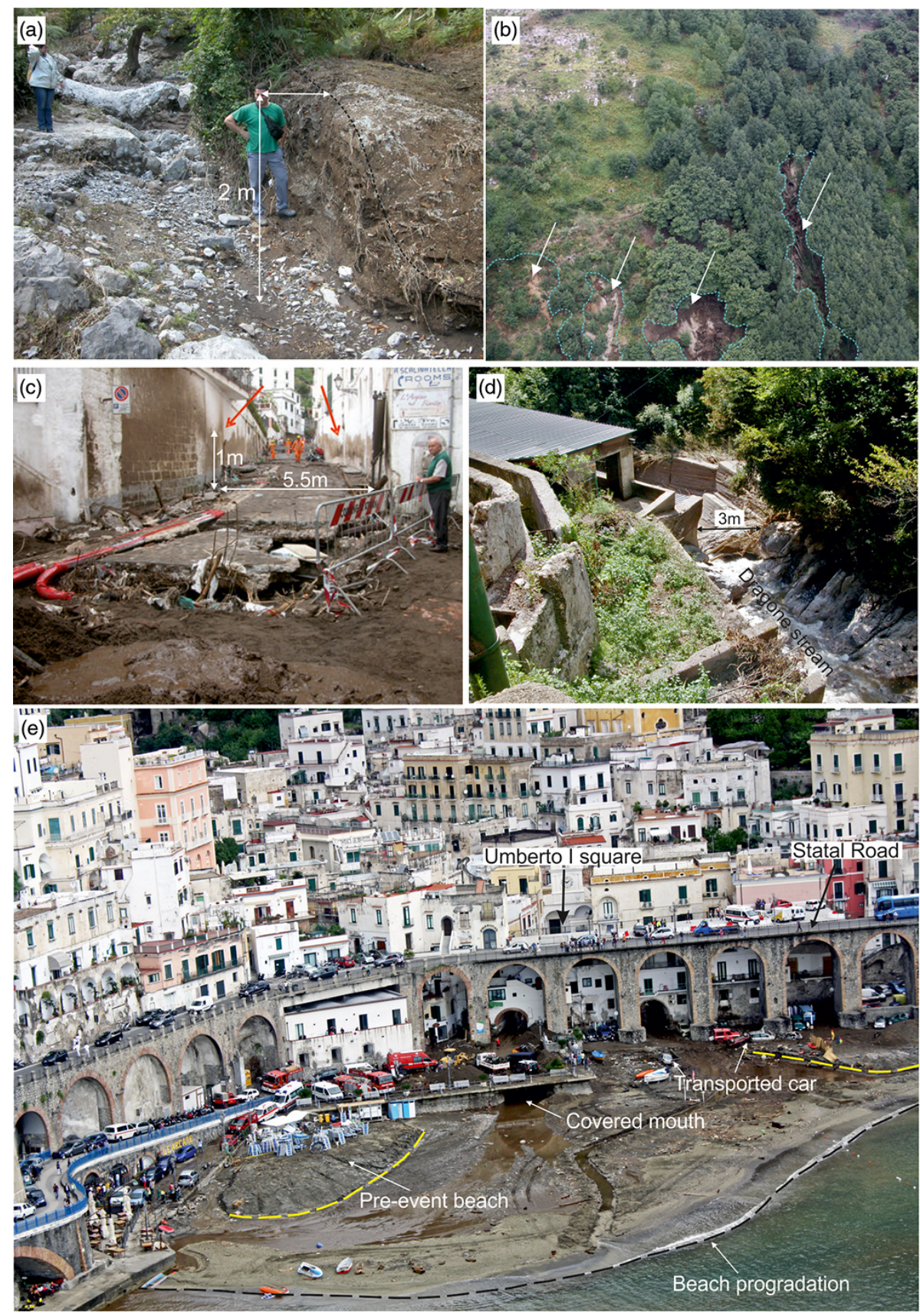

Figure 5. Geo-environmental effects induced by the 9 September 2010 rainstorm in the Dragone catchment. (a) Linear erosion engraving a tributary channel up to $2 \mathrm{~m}$. (b) Soil slip (arrows) at P. Castagne. (c) Partial breaking up of the main road (Via dei Dogi) in the village of Atrani. Red arrows indicate maximum height of the flow, reaching ca. $1 \mathrm{~m}$ above the street pavement. Location is shown in Fig. 13. (d) Site of temporary damming in correspondence of a man-made structure built in the stream bed. (e) Terminal fan at the mouth of the Dragone stream. See Fig. 3 for location.

streamflow activity, may be correlated with the Medieval Warm Period (ca. AD 900-AD 1100) and the Little Ice Age (ca. AD 1400-AD 1850).

\section{Rainstorm-induced geological effects}

A field survey was undertaken soon after the 9 September 2010 rainstorm in the Dragone catchment and village of Atrani. The observed rainstorm-induced geological effects include shallow landslides and sediment removal along chan- 
nels, a temporary dam in the mid-lower section of the Dragone stream, the partial breaking up of the main road crossing the village of Atrani, and the deposition of a coarse terminal fan at the mouth of the Dragone stream (Fig. 5).

The field data indicate that slope erosion triggered by the 9 September 2010 rainstorm was predominantly linear. Sediment removal by linear erosive processes significantly engraved tributaries and the main stream up to a depth of $2 \mathrm{~m}$ (Fig. 5a). The displaced materials were mostly composed of pyroclastic deposits and solid wastes occurring along the channel beds, often above the hydraulic check dams. A large number of tree trunks of different sizes, used to build bridges across ditches and tributaries, were also included in the transported material.

Minor soil slips have been observed uphill on the high slope at Punta delle Castagne, a rock crest connecting the S. Eustacchio, S. Caterina, and Scalandrone watersheds (Fig. 5b) and along the western flank of the Frezzi watershed. Here displacement of the channel sides occurred both at channel heads and, locally, at the middle-upper reaches of small tributaries.

Apart from overspill deposits composed of white pumices observed at break slopes just below the watershed areas and along the middle reach of the Dragone stream, no significant aggradation was observed in the catchment area. Removal of materials from the stream bed was produced by a fastmoving debris torrent with high erosive capacity, transporting the mobilized materials all the way down to the coast. Here the Dragone stream is artificially forced to flow underneath the main road crossing the village of Atrani, resulting in siphoning and consequent breaking up of the above roadway (Fig. 5c). Once it reached the coastline, the hyperconcentrated flow engraved the Atrani beach and dumped the transported materials into the sea in the form of a coarse alluvial fan (Fig. 5e). This induced a shore progradation of about $30 \mathrm{~m}$. The alluvial deposits entering into the sea were mostly composed of white-grey pumices including tree trunks, wastes, and rock boulders of different sizes reaching up to $1 \mathrm{~m}$ in diameter. Some cars parked along the main road were transported up to the beach area and beyond (Fig. 5e).

Despite the carbonate nature of the study area, there was no evidence of karst features that could have influenced the flooding mechanism. In fact the drainage of waters in the Amalfi Coast is mainly by relatively deep underground paths towards offshore springs located in correspondence of the main neotectonic lineaments (Celico et al., 2005). This may, at least in part, prevent direct interactions between groundwater and surface water during rainfall events as typically occurs in karst settings (Jourde et al., 2007; Gutierrez et al., 2014).

Discharge and depth of flow downstream was probably increased by abrupt draining of a temporary dam reported by eyewitnesses in the lower section of the Dragone stream. Such damming was favoured by a narrow flow section and enhanced by a man-made structure built in the stream bed
(Fig. 5d). The failure of temporary debris dams and the draining of ephemeral lakes have been described for different flood events that have occurred in the study area (Passerini, 1925; Penta et al., 1954). These phenomena can produce exceptional temporary discharges and highly destructive peak flows, reaching depths as high as 8-10 $\mathrm{m}$ (Larsen et al., 2001; Perez, 2001; Esposito et al., 2004; Violante, 2009).

\section{Synoptic description and physical features of the meteorological event}

The first days of September 2010 in the Mediterranean area were characterized by a drastic seasonal transition. The first depression from the Atlantic was favoured by the formation of a high-latitude anticyclone over Scandinavia. Such an anticyclone forced the oceanic perturbed airstream towards the medium European latitudes and the Italian peninsula. The unsettled air of Atlantic origin headed later for the low Tyrrhenian basin where very humid airstreams coming from south/south-west were forced by an area of low pressure centred in the northern Tyrrhenian Sea. This unstable scenario was fed by the Mediterranean Sea, which created conditions for a secondary area of low pressure to develop in the lower layers of the atmosphere.

The front was followed on 9 September 2010 by a far more organised instability in the southern Tyrrhenian basin with well-defined storm cells localized along the Campania, Sicily, and Calabria coastal areas. The high humidity associated with such a positive vorticity led to a mesoscale convective system (Fujita, 1986) over the southern Tyrrhenian Sea and southern Italy, as captured by a Meteosat image in the visible channel at 17:00 UTC (time hereafter expressed in UTC) on 9 September in Europe (Fig. 6a). The warm-humid flow associated with this system hit the Campania region, inducing a strong maritime thunderstorm between 10:00 and 22:00, with maximum intensity on the Lattari Mountains, as shown in the map of ground lightings (Fig. 6b).

The character of the convective system was conditioned by the Picentini and Lattari mountains that forced the air masses to follow the orography of the coastal range (see Fig. 1) and the positive anomalies of the coastal waters. Data from the Italian Oceanographic Network (ISPRA; Fig. 7) indicate that air temperature was lower than sea-surface temperature during the rainstorm, maintaining the thermodynamic conditions that allowed the convective system to sustain the storm cell.

Physical analysis of the rainstorm was based on the realtime data recorded by the rain gauges provided by the Centre for weather forecast and monitoring of the Campania regional authority (CEMPID, 2010; Table 1). On the coast the rainfall lasted $4 \mathrm{~h}$, starting at 14:10 east of Salerno (Fig. 8). At the Ravello rain gauge, located along the watershed of the Dragone basin, the rain started at 15:50 and persisted for about $1 \mathrm{~h}$ (cumulative rainfall $80.8 \mathrm{~mm}$ ) with a maximum rainfall intensity (19.4 mm over $10 \mathrm{~min}$; Table 1$)$ from 15:50 
Table 1. Rainfall intensity $(\mathrm{mm})$ registered at time intervals of $10 \mathrm{~min}$ and $1 \mathrm{~h}$ on September 9, 2010, by rain gauges in Salerno and the Sorrento peninsula. The maximum values are reported in bold. Data are from the Centre for weather forecast and monitoring of the Campania regional authority (CEMPID, 2010).

\begin{tabular}{lllllll}
\hline Rain gauge & Altitude $(\mathrm{m})$ & Latitude N & Longitude E & \multicolumn{2}{c}{ Distance from } \\
Ravello $(\mathrm{km})$ & \multicolumn{2}{c}{ Rainfall intensity $(\mathrm{mm})$} \\
& & & & & $10^{\prime}$ & $1 \mathrm{~h}$ \\
\hline Pontecagnano & 36 & $40^{\circ} 38^{\prime} 36.9^{\prime \prime}$ & $14^{\circ} 52^{\prime} 02.2^{\prime \prime}$ & 21.8 & 15.0 & 53.6 \\
Salerno Meteo & 16 & $40^{\circ} 38^{\prime} 37.7^{\prime \prime}$ & $14^{\circ} 50^{\prime} 11.5^{\prime \prime}$ & 20.3 & 16.0 & 47.0 \\
Ravello & 390 & $40^{\circ} 39^{\prime} 24.3^{\prime \prime}$ & $14^{\circ} 36^{\prime} 52.5^{\prime \prime}$ & 0.0 & 19.4 & 80.8 \\
Agerola Meteo & 848 & $40^{\circ} 38^{\prime} 48.6^{\prime \prime}$ & $14^{\circ} 32^{\prime} 26.2^{\prime \prime}$ & 6.0 & $\mathbf{2 6 . 2}$ & 80.8 \\
Agerola & 623 & $40^{\circ} 38^{\prime} 21.3^{\prime \prime}$ & $14^{\circ} 32^{\prime} 44.8^{\prime \prime}$ & 5.7 & 21.6 & 66.8 \\
Moiano & 485 & $40^{\circ} 39^{\prime} 12.6^{\prime \prime}$ & $14^{\circ} 27^{\prime} 50.0^{\prime \prime}$ & 13.5 & 21.0 & 78.0 \\
Pimonte & 437 & $40^{\circ} 40^{\prime} 27.8^{\prime \prime}$ & $14^{\circ} 30^{\prime} 17.4^{\prime \prime}$ & 10.2 & 23.2 & $\mathbf{9 2 . 2}$ \\
Maiori & 10 & $40^{\circ} 39^{\prime} 05.7^{\prime \prime}$ & $14^{\circ} 38^{\prime} 24.6^{\prime \prime}$ & 3.0 & 12.0 & 43.0 \\
Gragnano & 195 & $40^{\circ} 41^{\prime} 15.1^{\prime \prime}$ & $14^{\circ} 31^{\prime} 38.1^{\prime \prime}$ & 8.6 & 14.8 & 70.0 \\
Lettere & 312 & $40^{\circ} 42^{\prime} 15.9^{\prime \prime}$ & $14^{\circ} 31^{\prime} 58.3^{\prime \prime}$ & 9.8 & 16.2 & 45.6 \\
Corbara & 424 & $40^{\circ} 43^{\prime} 32.8^{\prime \prime}$ & $14^{\circ} 36^{\prime} 07.5^{\prime \prime}$ & 9.1 & 18.4 & 45.0 \\
Tramonti & 422 & $40^{\circ} 42^{\prime} 13.9^{\prime \prime}$ & $14^{\circ} 38^{\prime} 49.3^{\prime \prime}$ & 6.9 & 12.4 & 42.6 \\
Amalfi & 114 & $40^{\circ} 37^{\prime} 23.7^{\prime \prime}$ & $14^{\circ} 34^{\prime} 49.8^{\prime \prime}$ & 1.4 & 11.0 & 28.6 \\
Cetara & 140 & $40^{\circ} 39^{\prime} 04.0^{\prime \prime}$ & $14^{\circ} 42^{\prime} 12.5^{\prime \prime}$ & 8.6 & 9.8 & 27.2 \\
\hline
\end{tabular}

Table 2. Main morphometric parameters used in the hydrologic model.

\begin{tabular}{lllllll}
\hline Sub-basin & Name & $\begin{array}{l}\mathrm{A} \\
\left(\mathrm{km}^{2}\right)\end{array}$ & $\begin{array}{l}\mathrm{L} \\
(\mathrm{m})\end{array}$ & $\begin{array}{l}\mathrm{S} \\
(\%)\end{array}$ & $\begin{array}{l}\mathrm{H}_{\text {mean }} \\
(\mathrm{m} \text { a.s.1. })\end{array}$ & $\begin{array}{l}\mathrm{H}_{\text {min }} \\
(\mathrm{m} \text { a.s.1. })\end{array}$ \\
\hline Basin_1 & Scalandrone & 1.39 & 3600 & 56.7 & 873 & 389 \\
Basin_2 & Nocelle & 1.46 & 2450 & 60.5 & 922 & 479 \\
Basin_3 & Frezzi & 2.66 & 2600 & 54.3 & 803 & 479 \\
Basin_4 & Senite & 1.12 & 1000 & 46.7 & 570 & 389 \\
Basin_5 & Sant'Eustacchio & 2.71 & 3200 & 60.3 & 411 & 0 \\
\hline Whole basin & Dragone & 9.33 & 6800 & 56.5 & 692 & 0 \\
\hline
\end{tabular}

Table 3. Estimated lag-time values and the curve number $(\mathrm{CN})$ parameter used in the hydrologic model.

\begin{tabular}{llll}
\hline Sub-basin & $\begin{array}{l}\mathrm{CN} \\
(-)\end{array}$ & $\begin{array}{l}t_{\mathrm{c}} \\
(\mathrm{min})\end{array}$ & $\begin{array}{l}t_{\text {lag }} \\
(\mathrm{min})\end{array}$ \\
\hline Basin_1 & 66 & 44 & 26 \\
Basin_2 & 66 & 32 & 19 \\
Basin_3 & 66 & 34 & 20 \\
Basin_4 & 66 & 17 & 10 \\
Basin_5 & 66 & 38 & 23 \\
Whole basin & 66 & 72 & 43 \\
\hline
\end{tabular}

to 16:00. At the Agerola weather station, located about $5 \mathrm{~km}$ from the Dragone basin, the same event lasted about $1 \mathrm{~h}$ with an intensity rainfall peak of $157.2 \mathrm{~mm} \mathrm{~h}^{-1}$ from $16: 00$ to $16: 10$, showing a significant similarity with the cumulative rainfall of the Ravello gauge (see Fig. 8). This suggests that the Atrani event is consistent with a storm cell characterized by a very limited areal extent, as confirmed by the Meteosat visible image that shows a single cell with a very flat elliptical shape elongated in a NE-SW direction (inset in Fig. 6a).

The size of the storm cell that produced the Atrani event was calculated (1) by considering the $50 \mathrm{~mm}$ isohyet corresponding to the downdraught in the time span ranging from 16:00 to 16.50 (Fig. 9); and (2) on the basis of the number of pixels forming the storm cell visible in the Meteosat images at 17:00. In the first case the area was about $80 \mathrm{~km}^{2}$, while in the latter it ranged from 56 to $75 \mathrm{~km}^{2}$. Therefore, the Atrani storm cell can be ascribed to a mesoscale convective system (MCS) with a horizontal scale of about $20-30 \mathrm{~km}$ and duration of less than $1 \mathrm{~h}$ (lower bound of the MCS mesoscale $\beta$; Orlansky, 1975; Thunis and Borstein, 1996). These events typically occur in the Mediterranean Sea between April and September, with a higher frequency mostly concentrated during September (Lionello et al., 2006), and include multiple storm cells in different evolutionary stages (Morel and Senesi, 2002) that are strongly influenced by local orography. 


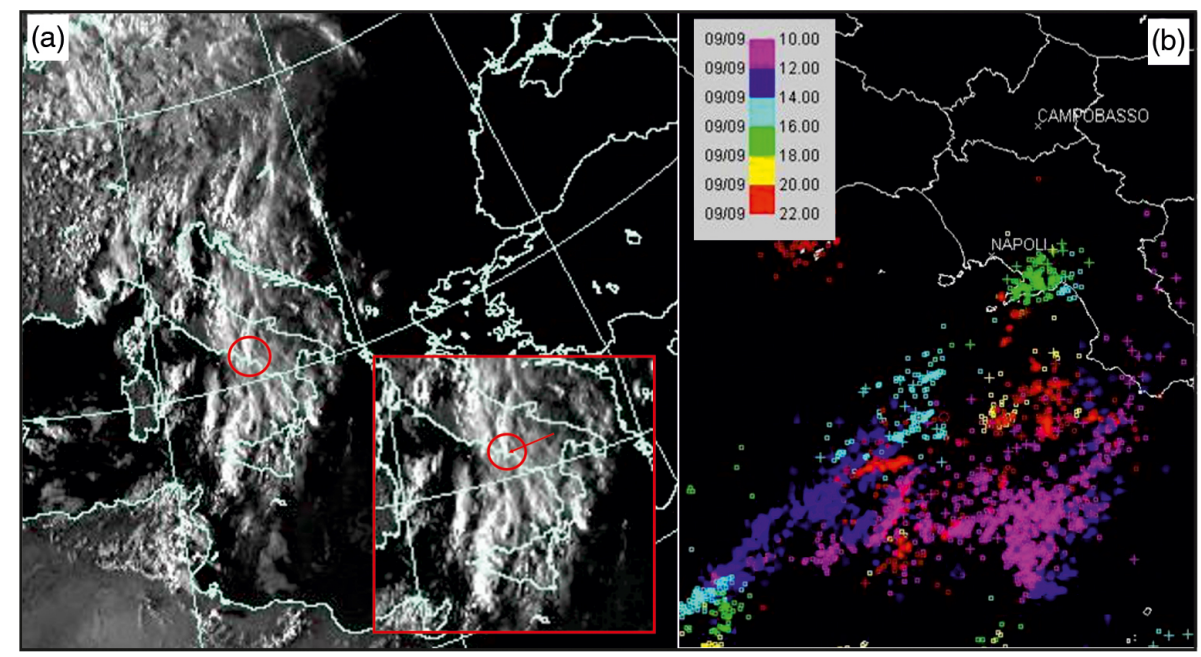

Figure 6. (a) Meteosat image captured in the visible channel on 9 September 2010 at 17:00 UTC (modified) showing a mesoscale convective system (MCS) over the southern Tyrrhenian Sea and southern Italy. Inset: detail showing the Atrani storm cell. (b) Thunderstorm activity on 9 September 2010. Intense electric activity is recorded between 14:00 and 16:00 (sky blue) near the city of Salerno and between 16:00 and 18:00 (green) on the Amalfi Coast.

\section{Hydrological model}

In order to evaluate the hydrological response of the Dragone basin at the stream mouth, a semi-distributed rainfallrunoff model has been used. For this purpose, each of the five sub-basins of the Dragone stream (see Fig. 3a and Table 2) were analysed by Soil Conservation Service (SCS) dimensionless unit hydrograph rainfall-runoff transformation, and SCS curve number (CN) loss method (USDA SCS, 1986a) implemented in HEC-HMS (USACE HEC, 2010).

The SCS dimensionless unit hydrograph procedure is one of the most well-known methods for deriving synthetic unit hydrographs, especially for small basins. The rainfall-runoff model is based on the lag time parameter, that is the time interval between the centroid of the effective rainfall hyetograph and the peak of discharge (Table 3; USDA SCS, 1986b; Singh, 1989).

The effective precipitation depth, according to the SCS$\mathrm{CN}$ procedure, is

$P_{\mathrm{e}}=\left\{\begin{array}{lll}\frac{\left(P-I_{\mathrm{a}}\right)^{2}}{\left(P-I_{\mathrm{a}}+S\right)} & \text { if } & P>I_{\mathrm{a}} \\ 0 & \text { if } & P \leq I_{\mathrm{a}}\end{array}\right.$.

$P$ is the total precipitation depth; $P_{\mathrm{e}}$ is the depth of excess precipitation or direct runoff; $I_{\mathrm{a}}$ is the "initial abstraction" or the amount of rain before the runoff starts, which infiltrates or is intercepted by vegetation; and $S$ is the potential maximum soil moisture retention during the runoff.

The value of $S$ for a given soil is related to the curve number $(\mathrm{CN})$ which is a function of the hydrologic soil-cover complexes as (if $S$ is expressed in $\mathrm{mm}$ )

$\mathrm{CN}=\frac{25400}{S+254}$.
In the case of the Dragone basin, the adopted $\mathrm{CN}$ value is 66 , corresponding to forest-like cover (woods-grass combination), considering hydrological soil group B (moderate infiltration) with antecedent moisture condition II (average) and $I_{\mathrm{a}}=0.2 \mathrm{~S}$.

The lag time $t_{\text {lag }}$ has been estimated from the concentration time $t_{\mathrm{c}}$ calculated by the SCS formula (Chow et al., 1988):

$t_{\text {lag }}=0.6 \times t_{\mathrm{c}}=0.6 \times 0.00227$

$\times L^{0.8}\left(\frac{1000}{\mathrm{CN}}-9\right)^{0.7} i^{-0.5}[$ hour $]$.

$L$ is the hydraulic watershed length expressed in metres (m) and $i$ the mean basin slope as a percentage (\%). Figure 10 reports the results of the hydrological model where the estimated peak discharge of the clear water is about $65 \mathrm{~m}^{3} \mathrm{~s}^{-1}$ occurring around 17:00.

\section{Hydraulic model and sediment transfer}

Due to the lack of stream gauge data, we analysed the hydraulic response of the Dragone catchment to the 9 September 2010 rainstorm event and the sediment transfer during the flood on the basis of (a) morphology of the Dragone basin, (b) pluviometric data, (c) field evidences, (d) homemade videos and photos, and (e) eyewitness accounts.

According to local eyewitness accounts, the peak flow of the Atrani flood event occurred between 16:50 and 17:10, which is about $40 \mathrm{~min}$ later than the hyetograph centroid, at about 16:25, while the flood duration ranged from 40 to $60 \mathrm{~min}$ (Fig. 11). In the Atrani urban area the covering of the Dragone stream caused the flood wave to be split 

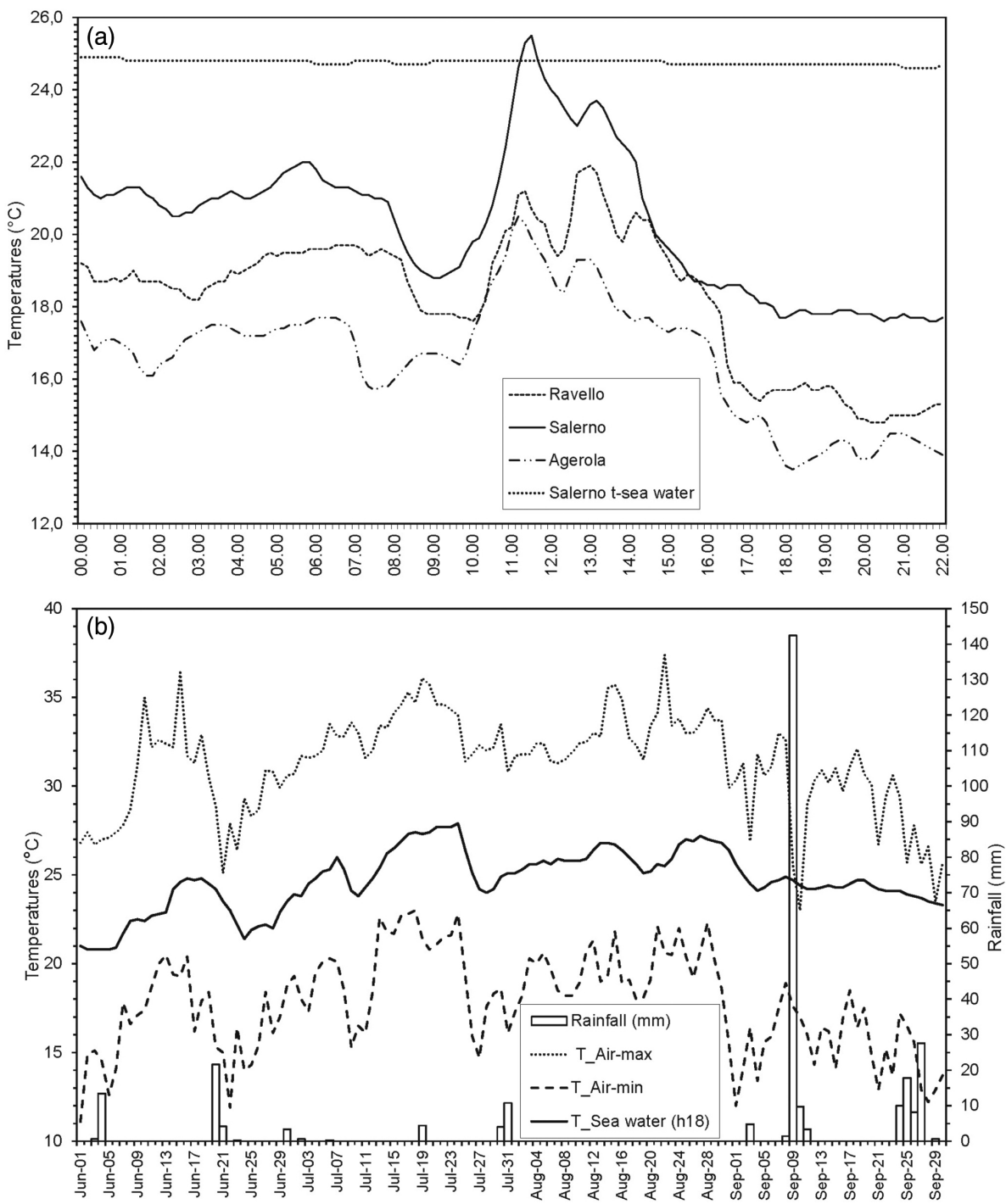

Figure 7. (a) Rainfall intensity and air ( $\min$ and $\max$ ) and sea water temperatures measured at Salerno from 1 June to 30 September 2010; (b) air and sea water temperatures at $10 \mathrm{~min}$ intervals on 9 September 2010. Data are from the Centre for weather forecast and monitoring of the Campania regional authority (CEMPID, 2010).

into two different currents: a main flow underground, below the road level (Via Dei Dogi), along a closed section varying from $3(h) \mathrm{m} \times 9(w) \mathrm{m}$ at the input section to $1.80(h)$ $\mathrm{m} \times 5.50(w) \mathrm{m}$ at the closing section; and a second flow at the surface, along the road, constrained by almost continuous man-made structures and buildings $5.5 \mathrm{~m}$ away from each other (see Fig. 5c). The maximum depth of the upper flow was about $1 \mathrm{~m}$, i.e. $3.5 \mathrm{~m}$ on average above the stream bed.

The highest flow velocity for both flows was estimated from amateur videos by tracking particles transported by the flood through the analysis of video frames with an approach similar to that used in the particle image velocimetry technique (Fig. 12; Raffel et al., 2007). Peak discharge was ob- tained by multiplying estimated flow velocity and the flow section.

The estimated flow velocity along Via Dei Dogi is about $3-4 \mathrm{~m} \mathrm{~s}^{-1}$ and, consequently, the peak discharge is approximately $20 \mathrm{~m}^{3} \mathrm{~s}^{-1}$. For the underground flow the estimated peak velocity is about $6-7 \mathrm{~m} \mathrm{~s}^{-1}$, while the peak discharge is on the order of $60 \mathrm{~m}^{3} \mathrm{~s}^{-1}$, taking into account that the flow fills roughly $80 \%$ of the closed section. Then the total estimated peak discharge is $80 \mathrm{~m}^{3} \mathrm{~s}^{-1}$ (water + sediment; see Fig. 11), which is $15 \mathrm{~m}^{3} \mathrm{~s}^{-1}$ more than the estimated clear water peak discharge $\left(65 \mathrm{~m}^{3} \mathrm{~s}^{-1}\right)$ due to sediment load $\left(Q_{\mathrm{s}}\right)$. Similar values for total peak discharge $\left(98.4 \mathrm{~m}^{3} \mathrm{~s}^{-1}\right)$ have been reported by Ciervo et al. (2014), who used a dedicated numerical code for the hydraulic modelling of the 9 September 2010 Atrani flash flood. 


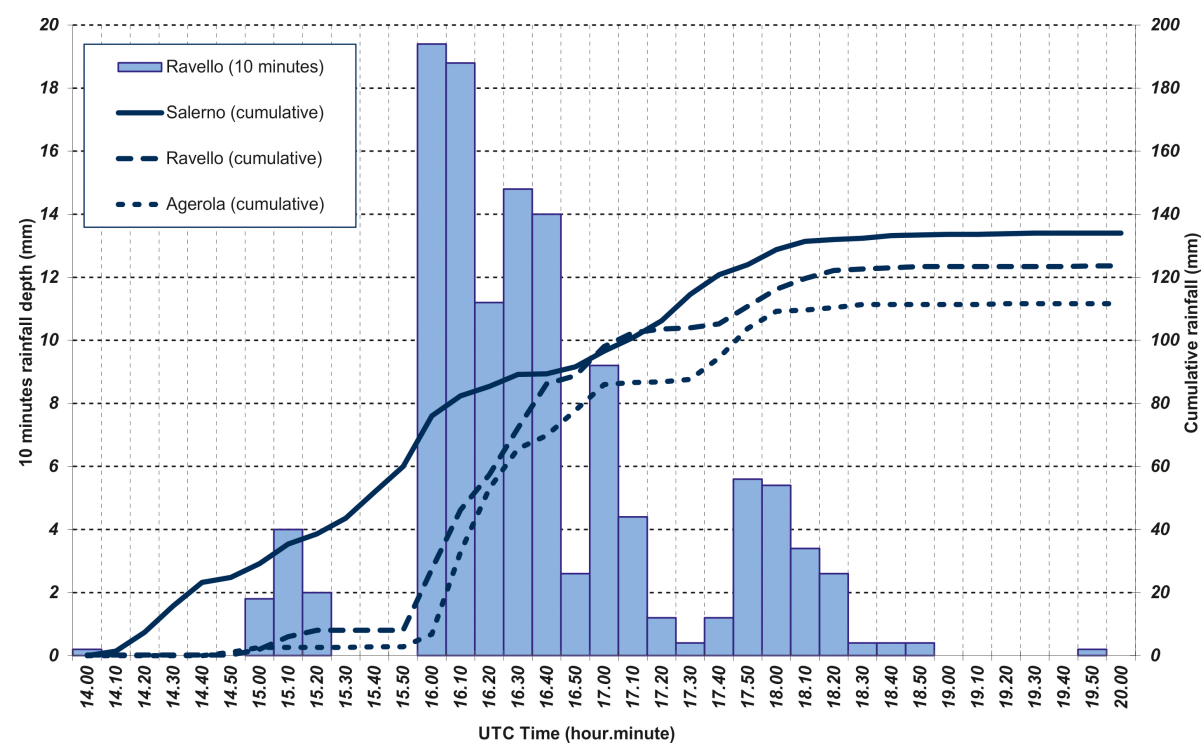

Figure 8. Cumulative rainfall at 10 min intervals on 9 September 2010, from 14:00 to 20:00 UTC, as recorded by the rain gauges of Salerno, Ravello, and Agerola. Rainfall intensity at Ravello rain gauge is also reported. Data are from the Centre for weather forecast and monitoring of the Campania regional authority (CEMPID, 2010).

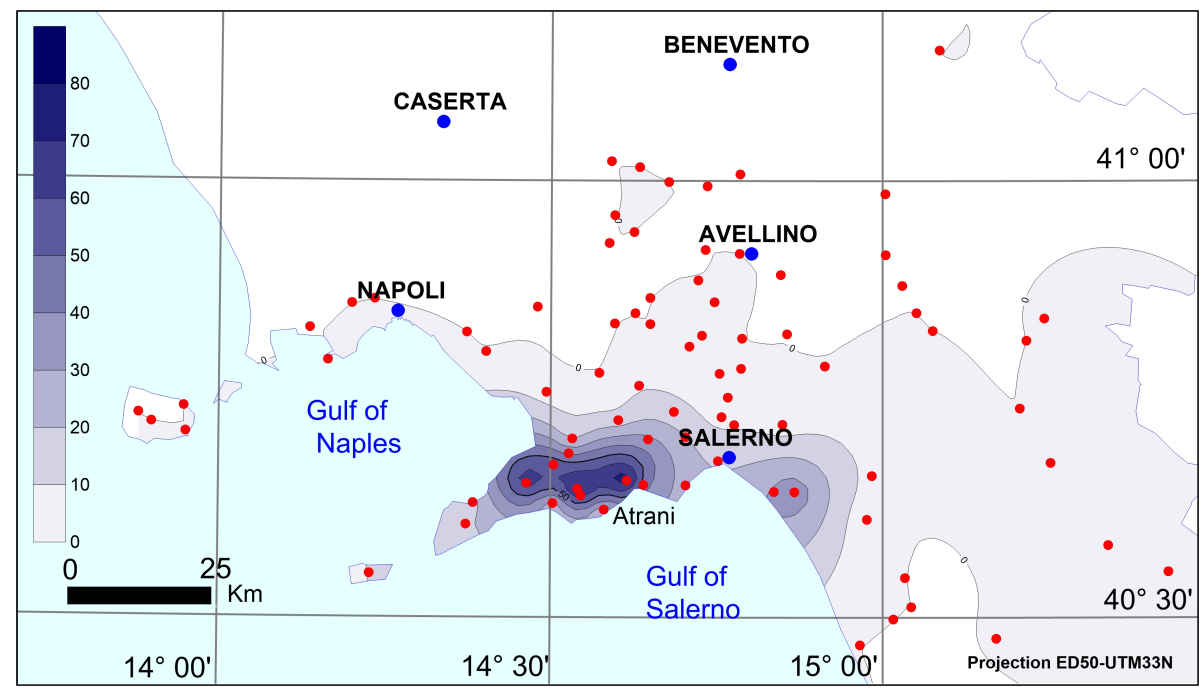

Figure 9. Isohyetal map of the cumulated rainfall from 16:00 to 16:50 UTC. Red dots denote rain gauges.

Assuming that active sediment removal occurred in a time span of $40 \div 60 \mathrm{~min}$, the calculated sediment volume mobilized during the event is

$$
\begin{aligned}
& V_{\mathrm{s}}=Q_{\mathrm{s}} \times t=15 \times \frac{(40 \div 60)}{2} \times 60 \\
& =18000 \div 27000 \mathrm{~m}^{3} .
\end{aligned}
$$

This value is in good agreement with the volume estimation of the sediments deposited in the form of an alluvial fan delta at the Dragone mouth and on the street and square that cover the stream path (Fig. 13). Comparison of bathymetric data collected soon after the flood event with an older data set owned by IAMC-Napoli enabled the measurement of the sediment volume that flowed into the sea, at about $14000 \mathrm{~m}^{3}$ (Fig. 13). On land, sediment thickness along Via Dei Dogi and Umberto I square reached depths averaging $0.5 \mathrm{~m}$, while beach aggradation was about $1 \mathrm{~m}$, with a volume of sediment accumulation of about $7000 \mathrm{~m}^{3}$. Therefore, the estimated volume of the sediment transported to the terminal section of the Dragone stream is about $21000 \mathrm{~m}^{3}$. Taking into account the additional volumes (estimated at about $20 \%$ of the measured volume) removed by the sea currents, or related to dispersal of finer sediments at sea, a total volume of about $25000 \mathrm{~m}^{3}$ can be obtained. 


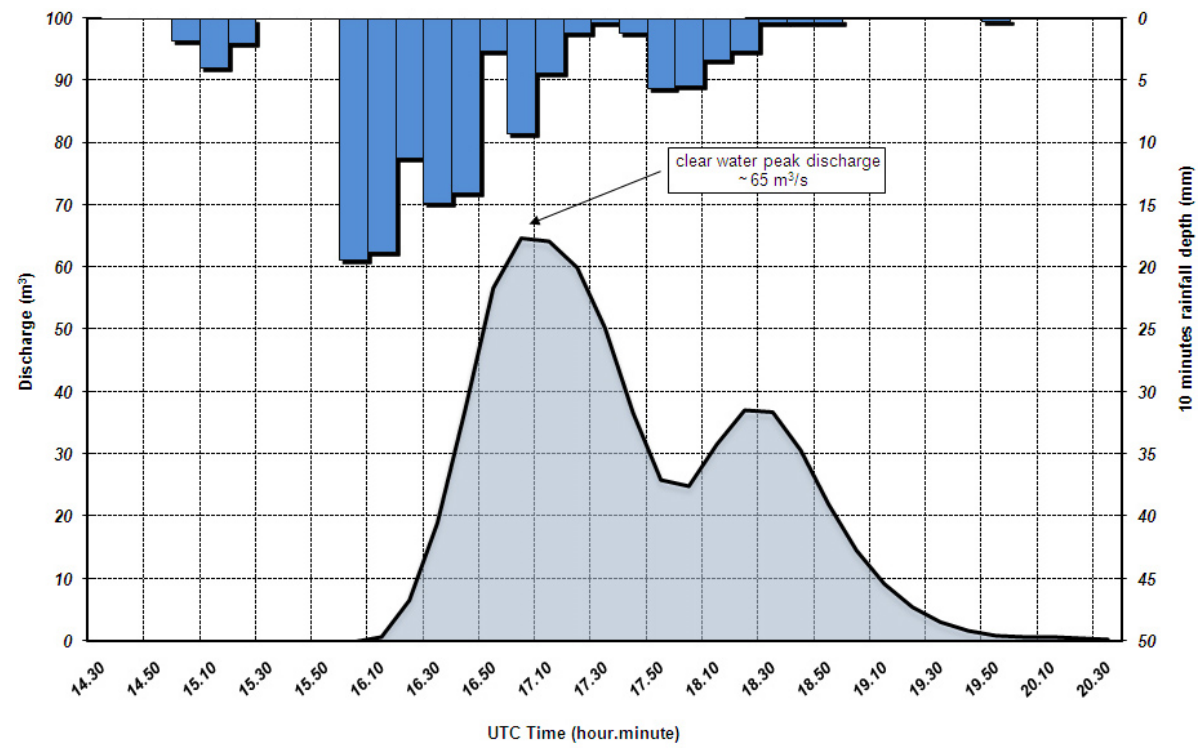

Figure 10. Clear water hydrograph resulting from the hydrological model.

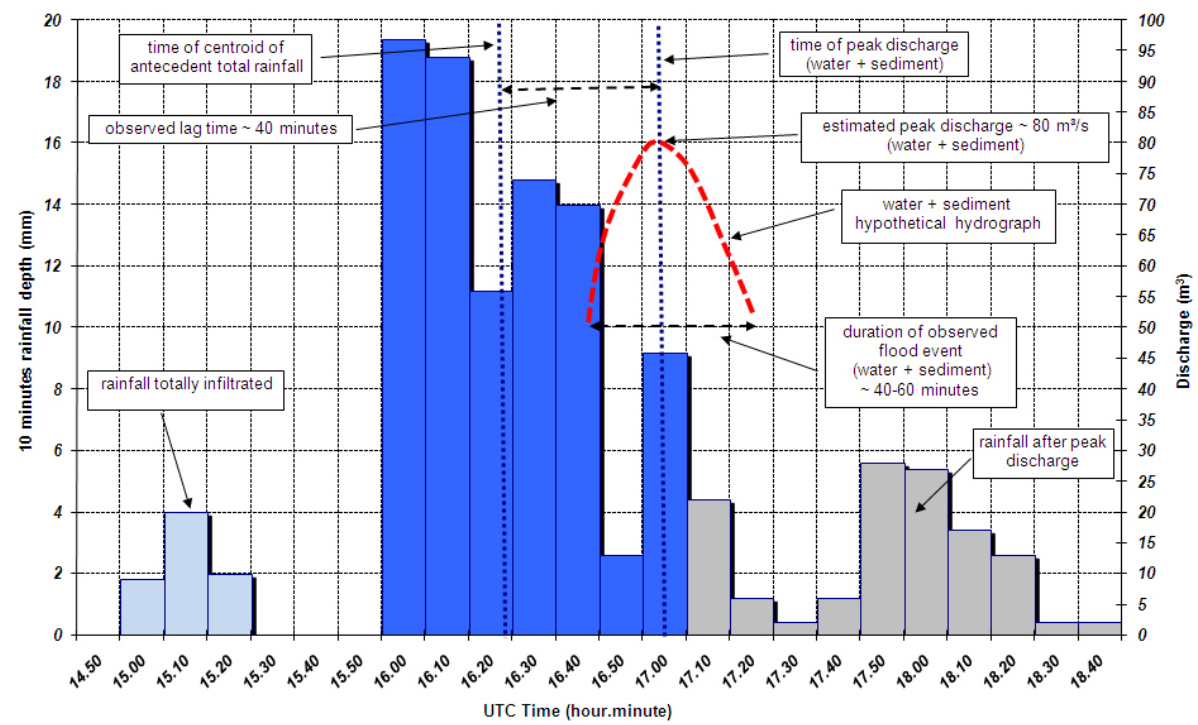

Figure 11. Hyetograph and estimated flood peak discharge.

Sediment volume can be expressed as sediment bulking factor (BF; Gusman et al., 2009) that defines the ratio between the peak flood discharge $Q_{\mathrm{B}}$ and clear water discharge $\left(Q_{\mathrm{w}}\right)$ :

$\mathrm{BF}=\frac{Q_{\mathrm{B}}}{Q_{\mathrm{w}}}=\frac{Q_{\mathrm{w}}+Q_{\mathrm{s}}}{Q_{\mathrm{w}}}$.

In terms of sediment load, bulking factor can be also expressed as

$\mathrm{BF}=\frac{1}{1-\frac{C_{\mathrm{V}}}{100}}$.

$C_{\mathrm{V}}$ is the volume concentration of sediment.
In the case of the 9 September 2010 flood event the estimated BF to the flood peak is $1.2(5)$ that leads to a sediment concentration on the order of $20 \%$ in volume (6). This value is close to the lower limit of hyperconcentrated flow (Costa, 1988; Jakob and Hungr, 2005) and it corresponds to a flow in which peak discharge is comparable to that of a clear water flood, and velocities are similar to those of water during a flood (Hungr et al., 2001; Pierson, 2005). This is also confirmed by amateur videos that show a very turbulent flow. 

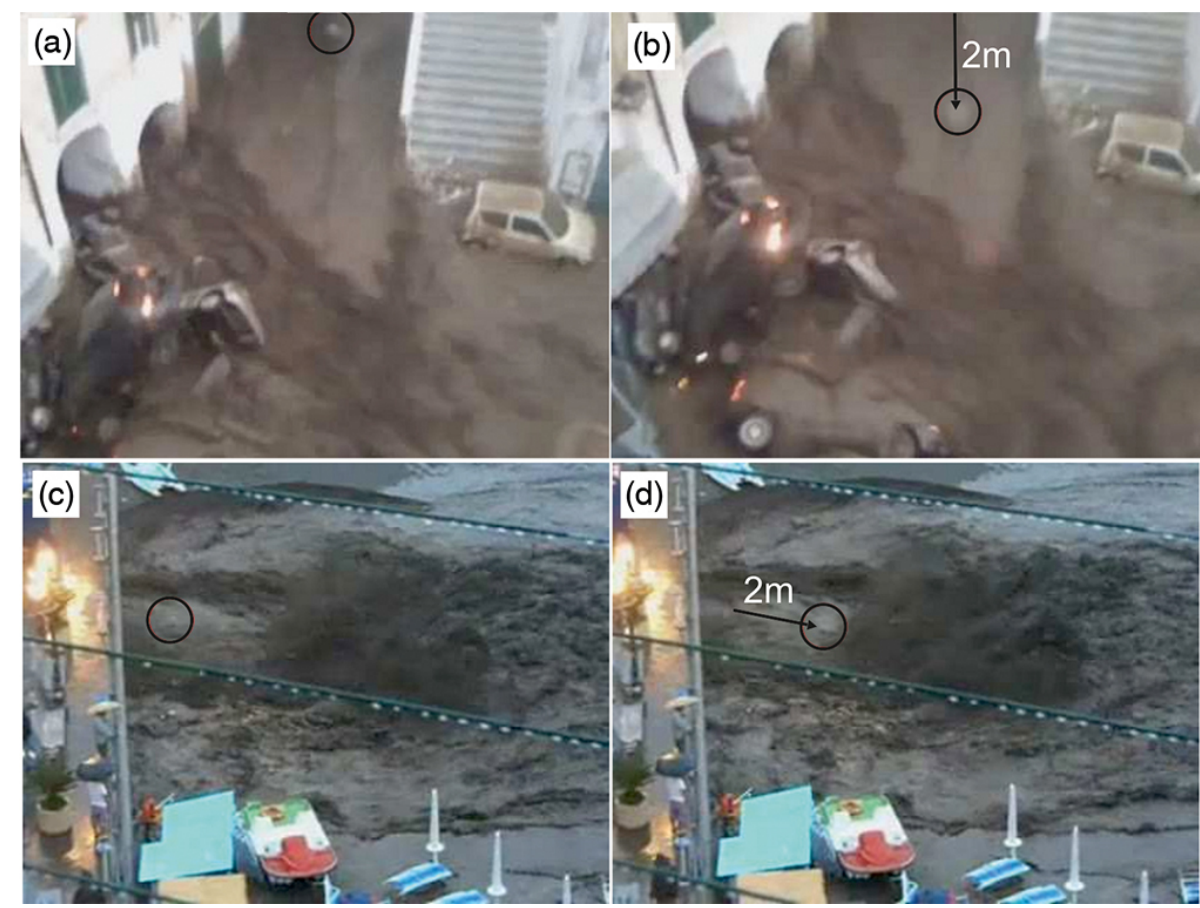

Figure 12. Estimation of flow velocity from amateur videos by tracking selected particles (black circles) transported by the floods. Panels (a) and (b) show the upper flow along Via Dei Dogi. Panels (c) and (d) show underground flow at the Dragone stream mouth. Location in Fig. 13. See text for discussion.

\section{Historical documentation of past floods}

Historical records are an important source of information on floods and fundamental to establish a reliable flood return frequency. The potential of historical data is based on their value as repositories of the magnitude and characteristics of flood events by indicating the level of damage, the number of victims, as well as the type of the induced geological effects (e.g. Calcaterra and Parise, 2001; Tropeano and Turconi, 2004; Marchi and Tecca, 2006). This is particularly true for the Campania region, an area with a long history and much documentation, where historical research is crucial for hydrogeological risk assessment in the perspective of proper land use planning, damage mitigation, and reduction of human fatalities.

In the study area the systematic analysis of more than 3000 documents, including documentary and bibliographic sources, as well as newspapers at the state archives in Naples and Salerno (Esposito et al., 2003, 2004; Porfido et al., 2009), complemented by data attained from scientific papers and national and international projects (Guzzetti et al., 1994; Guzzetti and Tonelli, 2004), allowed the time-space distribution and the characteristics of flood events that have occurred since 1540 to be reconstructed. The quality and completeness of the various sources were evaluated and carefully analysed in their historical context, to obtain the best information rather than the best data set quality (Calcaterra and Parise, 2001; Barriendos et al., 2003). Eighteen events, ex- cluding the one discussed in the present paper, were identified and characterized on the basis of (a) the distribution of the flooded areas, (b) distribution of damaged localities, (c) duration and timing of the event, and (d) number of casualties. The historical information shows that most of the events ( 13 events) took place at the transition between summer and autumn, four events were in winter, while only one was recorded during the spring season (Table 4).

The intensity and the duration of the rainfall, the level and distribution of damage of man-made structures, the number of victims, and the induced geological effects have been considered to distinguish major flash floods from minor flash floods (Table 4; Casas Planes et al., 2003; Llasat et al., 2005; Barnolas and Llasat, 2007). In particular, shoreline progradation has been considered as a key element for major flash floods as it results from significant bed load transport and hyperconcentrated streamflows. Based upon the above assumptions, the following 6 flood events out of the total of 18 have been classified as major flash floods.

- October 1540: not much information is available for this event, but it is reported as "the great Atrani flood". This indication, along with the occurrence of severe damage and extensive landslides and inundation, allows it to be classified as a flash flood.

- August 1588: this was a flood that produced severe damage to properties, extensive inundation, landslides and shoreline progradation, as reported by the Cronaca 


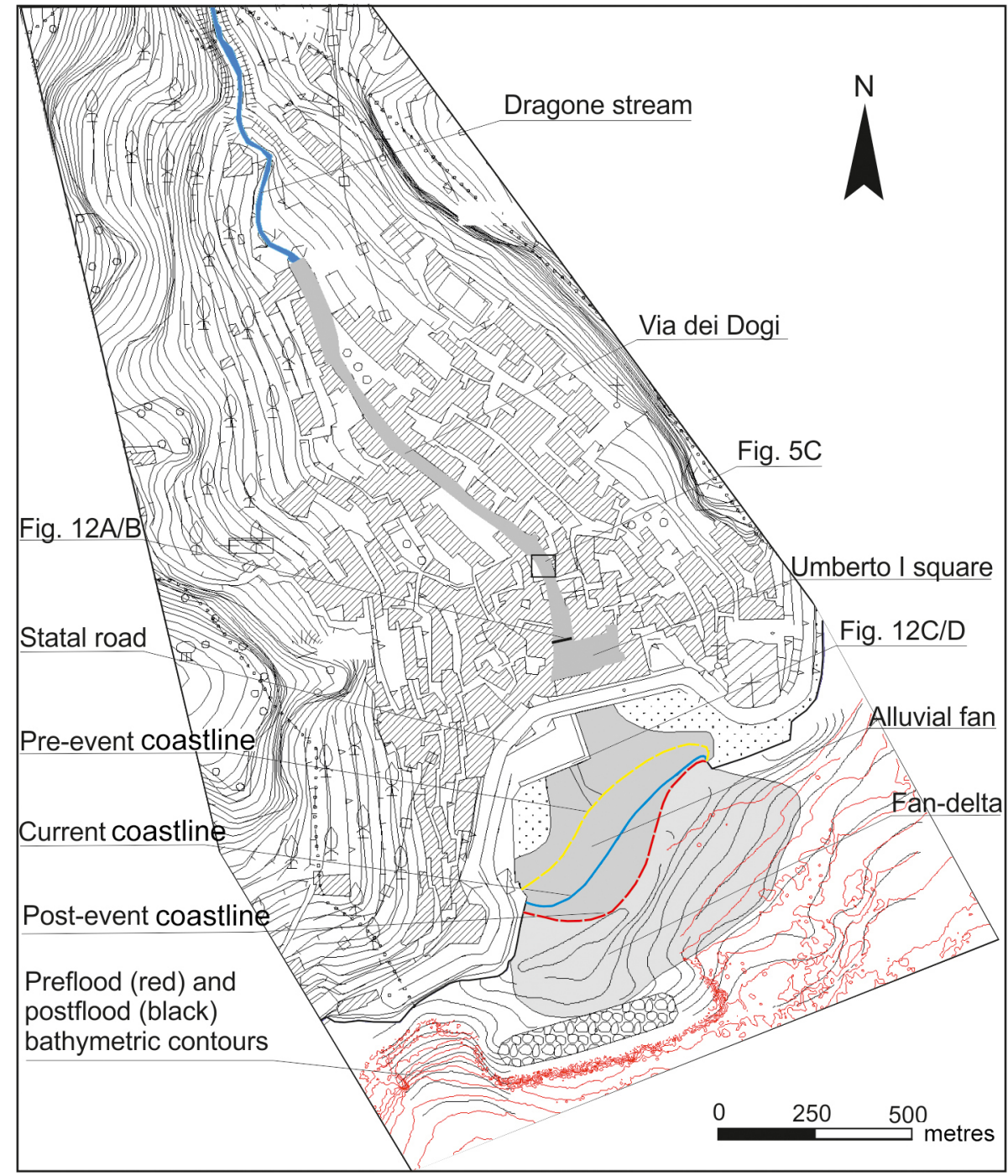

Figure 13. Map of the flooded area with indication of the alluvial fan and the submerged fan delta.

Amalphitana, Ignoti auctoris 1588 , cited by Camera (1881): "at the end of the past month of August 1588 much lava fell down ... it destroyed the Seggio building ... the force of the lava removed trees, wood, earth and rocks and ... it filled the harbour and pushed the sea back seven roads (14 $\mathrm{m}$ ) thereby enlarging the harbour".

- 20 January 1764: this flood caused much damage to the Santa Maria Acquabona church and to many flour mills as well as to some bridges. Extensive landslides coming from Scala hit Atrani, causing two deaths. The sediment transfer from Scala to Atrani indicates a mass transport along the main stream, likely produced by a flash flood.

- 17 January 1780: heavy rain hit the village of Atrani, causing 26 casualties, a huge landslide, and extensive damage (Greco, 1787). The elevated number of victims suggests a flash flood event.
- 18 August 1949: on 18 August, water masses flooded along the main street and square of Atrani, reaching a height of about $3 \mathrm{~m}$. A widespread pattern of destruction characterized this event: boats, nets, and fishing gear were swept away or submerged by mud; there was also damage to buildings, destruction of roads, aqueducts, and sewer systems. Thousands of cubic metres of material and muddy debris were left in the Umberto I square as well as on the beach, producing a shoreline progradation of about $20 \mathrm{~m}$.

- 1 October 1949: the effects of the past flood events were still evident when a second one occurred with greater violence. The breaking up of the main street occurred at several places, and water supply pipelines, recently refitted, were destroyed again. Huge amounts of debris and mud were transported all the way down to the coast in addition to the material recently transported by the 18 
Table 4. Flood events occurred at Atrani from 1540 to August 2010 with indication of the induced effects. MF: major flash flood. Mf: minor flash flood.

\begin{tabular}{|c|c|c|c|c|c|c|}
\hline Year & Month & Day & Damage & Victims & $\begin{array}{l}\text { Geological } \\
\text { effect }\end{array}$ & $\begin{array}{l}\text { Flood } \\
\text { type }\end{array}$ \\
\hline 1540 & 10 & 8 & Severe & - & Slides & MF \\
\hline 1588 & 8 & 31 & Major & Some & $\begin{array}{l}\text { Shoreline } \\
\text { progradation }\end{array}$ & MF \\
\hline 1764 & 1 & 20 & Major & 2 & & $\mathrm{MF}$ \\
\hline 1780 & 1 & 17 & Severe & 26 & & $\mathrm{MF}$ \\
\hline 1823 & 10 & 18 & Minor & & & Mf \\
\hline 1824 & 10 & 3 & Minor & & & Mf \\
\hline 1904 & 10 & 7 & Minor & & & Mf \\
\hline 1924 & 3 & 27 & Minor & & Slides & Mf \\
\hline 1935 & 3 & 1 & Minor & & & Mf \\
\hline 1949 & 8 & 18 & Major & & $\begin{array}{l}\text { Shoreline } \\
\text { progradation }\end{array}$ & MF \\
\hline 1949 & 10 & 1 & Major & & $\begin{array}{l}\text { Shoreline } \\
\text { progradation }\end{array}$ & MF \\
\hline 1953 & 9 & 11 & Minor & & & Mf \\
\hline 1954 & 10 & 25 & Minor & & & Mf \\
\hline 1969 & 3 & 15 & Minor & & & Mf \\
\hline 1984 & 8 & 28 & Minor & 1 & & Mf \\
\hline 1987 & 10 & 6 & Minor & & & Mf \\
\hline 1988 & 9 & 14 & Minor & & & Mf \\
\hline 2007 & 9 & 20 & Minor & & & Mf \\
\hline
\end{tabular}

August flood, so that a large beach developed at the foot of coastal cliffs, between the village of Atrani and the nearby locality of Castiglione.

\section{Conclusions}

Detailed field surveys and measurements, along with information from eyewitnesses and home-made videos, proved to be critical for reconstructing and modelling the flash flood that affected the village of Atrani on 9 September 2010. The collected data were combined with meteorological and historical analyses and marine geophysical surveys in order to reconstruct the physical features of the flood event and to evaluate the recurrence of flash floods in the study area. The main results can be summarized as follows.

- The rainstorm that generated the Atrani event lasted $4 \mathrm{~h}$ and was strongly conditioned by the local orography and positive thermic anomalies of the coastal waters during the warm season.

- In Atrani the rainfall event lasted about $1 \mathrm{~h}$ with cumulative rainfall of $80.8 \mathrm{~mm}$ and maximum rainfall intensity of nearly $120 \mathrm{~mm} \mathrm{~h}^{-1}$. It was produced by a single storm cell elongated in a NE-SW direction, with a very flat elliptical shape and of limited areal extent (from 50 to $70 \mathrm{~km}^{2}$ ) that can be ascribed to a $\beta$ type mesoscale convective system.
- The estimated peak discharge of the clear water produced in the Dragone stream is about $65 \mathrm{~m}^{3} \mathrm{~s}^{-1}$ while the estimated total peak discharge (water + sediment) is $80 \mathrm{~m}^{3} \mathrm{~s}^{-1}$, leading to a sediment concentration of about $20 \%$ in volume.

- Sediment removal mostly occurred through linear erosion that significantly engraved tributaries and the main stream. The displaced materials were mostly composed of pyroclastic deposits and solid wastes occurring at the channel beds and behind the hydraulic check dams. A reduced size of erodible sediment stored in channels may consequently reduce the mud-flow hazard and provide protection for the residential area on the alluvial fan in Atrani.

- The analysis of historical sources shows that 18 flood events occurred in the Dragone catchment in the last five centuries. Six events were classified as major flash floods and twelve as minor flash floods. The internal stratigraphic architecture of the Dragone fan delta confirms the recurrence of floods in the Early Medieval Cool Period (ca. AD 500-AD 800), in the Medieval Warm Period (ca. AD 900-AD 1100), and the Little Ice Age (ca. AD 1400-AD 1850).

The approach used in this work is representative of geomorphological and urban settings characterized by very small ungauged and rocky watersheds with ephemeral discharge, 
and local communities mostly living at the stream mouths. In these settings the importance of erosional processes claim the use of different data sources for predictive water models that include geological and hydrological analyses.

Acknowledgements. The authors wish to thank Crescenzo Minotta, geologist at Autorità di Bacino Campania Sud, and Maria Carla Sorrentino, archaeologist and member of the "Centro Universitario Europeo per i Beni Culturali" for support with post-event bathymetric survey and assistance in the field, respectively. We also thank Luigi Amato of the Cultural Association "Sos Dragone" that helped to reconstruct the timing of the flooding event. This work was funded by a research grant CUP: G23F11000790004 to Crescenzo Violante. Two anonymous referees are thanked for their constructive comments on the submitted manuscript.

Edited by: M. Parise

Reviewed by: two anonymous referees

\section{References}

Barnolas, M. and Llasat, M. C.: A flood geodatabase and its climatological applications: the case of Catalonia for the last century, Nat. Hazards Earth Syst. Sci., 7, 271-281, doi:10.5194/nhess-7271, 2007

Barriendos, M., Llasat, M. C., Barrera, A., and Rigo, T.: The study of flood events from documentary sources, Methodological guidelines for historical sources identification and flood characterization in the Iberian Peninsula, in: Palaeofloods, Historical Floods and Climatic Variability: Applications in Flood Risk Assessment (Proceedings of the Phefra Workshop, Barcelona, 1619 October, 2002), edited by: Thorndycraft, V. R., Benito, G., Barriendos, M., and Llasat, M. C., 87-92, 2003.

Budillon, F., Violante, C., Conforti, A., Esposito, E., Insinga, D., Iorio, M., and Porfido, S.: Event beds in the recent prodelta stratigraphic record of the small flood-prone Bonea Stream (Amalfi Coast, Southern Italy), Marine Geology, 222-223, 419-441, 2005.

Calcaterra, D. and Parise, M.: The contribution of historical information in the assessment of the landslide hazard, in: The Use of Historical Data in Natural Hazard Assessments, edited by: Glade, T., Albini, P., and Frances, F., Adv. in Nat., and Tech. Hazards Res., 17, Kluwer Academic Publishers, 201-217, 2001.

Calcaterra, D., Parise, M., and Palma, B.: Combining historical and geological data for the assessment of the landslide hazard: a case study from Campania, Italy, Nat. Hazards and Earth System Sciences, 3 (1/2), 3-16, 2003.

Camera, M.: Memorie storico diplomatiche dell'antica città e ducato di Amalfi, (reprinted Centro Cultura e Storia amalfitana, Amalfi, 1999), 80 pp., 1881.

Casas Planes, A., Benito, G., Díez Herrero, A., and Barriendos, M.: Sphere-Gis: Implementation of an historical and palaeoflood geographical information system, in: Palaeofloods, Historical Floods and Climatic Variability: Applications in Flood Risk Assessment (Proceedings of the Phefra Workshop, Barcelona, 16th19th October, 2002), edited by: Thorndycraft, V. R., Benito, G., Barriendos, M., and Llasat, M. C., 363-368, 2003.
Celico, P., De Vita, P., Monacelli, G. Scalise, A. R., and Tranfaglia, G.: Hydrogeological map of southern Italy. APAT, Università di Napoli "Federico II", Programma INTERREG IIC - Territory regulation and contrast to the drought, Sottoprogetto "Hydrological cycle analysis", 55 pp., 2005

CEMPID: Centro funzionale per la previsione meteorologica e il monitoraggio meteo pluvio idrometrico e delle frane: Rapporto dell'evento del 9 Settembre 2010 nel territorio dei comuni di Scala ed Atrani, Napoli, 38 pp., 2010.

Chow, V. T., Maidment, D. R., and Mays, L. W. (Eds): Applied Hydrology, McGraw Hill New York, 572 pp., 1988.

Ciervo F., Papa M. N., Medina V., and Bateman A.: Simulation of flash floods in ungauged basins using post-event surveys and numerical modelling, J. Flood Risk Manage., 1-13, 2014.

Cinque, A. and Robustelli, G.: Alluvial and coastal hazards caused by long-range effects of Plinian eruptions: the case of the Lattari Mts. After the AD 79 eruption of Vesuvius, in: Geohazard in Rocky Coastal Areas, edited by: Violante C., Geological Society of London, Special Publications, 322, 155-171, doi:10.1144/SP322.7, 2009.

Costa, J. E.: Rheologic, geomorphic, and sedimentologic differentiation of water floods, hyperconcentrated flows, and debris flows, in: Flood Geomorphology edited by: Baker, V. R., Kochel, R. C., and Patten, P. C., Wiley-Intersciences, New York, 113-122, 1988.

Esposito E., Porfido S., Violante C., and Alaia F.: Disaster induced by historical floods in a selected coastal area (southern Italy), in: Palaeofloods, Historical Floods and Climatic Variability: Applications in Flood Risk Assessment (Proceedings of the Phefra Workshop, Barcelona,16-19 October, 2002), edited by: Thorndycraft, V. R., Benito, G., Barriendos, M., and Llasat, M. C., 143-148, 2003.

Esposito, E., Porfido, S., Violante, C., Biscarini, C., Alaia, F., and Esposito, G.: Water events and historical flood recurrences in the Vietri sul Mare coastal area (Costiera Amalfitana, southern Italy), in: The Basis of Civilization - Water Science?, edited by: Rodda, G., and Ubertini, L., International Association of Hydrological Sciences Publication, 286, 1-12, 2004.

Fujita, T. T.: Mesoscale classifications: their history and their application to forecasting, in: Mesoscale Meteorology and Forecasting, edited by: Ray, P. S., American Meteorological Society, Boston, 18-35, 1986.

Greco, M.: Cronaca di Salerno, Reprinted Palladio Salerno, 36 pp., 1787.

Gusman, A. J., Teal, M. J., Todesco, D., and Bandurraga, M.: Estimating Sediment/Debris Bulking Factors, in: Proceeding of 33rd IAHR Congress, Vancouver, British Columbia, Canada, 9-14 August 2009, 83-91, ISBN: 978-1-61738-231-4, 2009.

Gutierrez, F., Parise, M., De Waele, J., and Jourde H.: A review on natural and human-induced geohazards and impacts in karst, Earth Science Rev., 138, 61-88, doi:10.1016/j.earscirev.2014.08.002, 2014.

Guzzetti, F., Cardinali, M., and Reichenbach, P.: The AVI Project: A bibliographical and archive inventory of landslides and floods in Italy, Environ. Manage., 18, 623-633, 1994.

Guzzetti, F. and Tonelli, G.: Information system on hydrological and geomorphological catastrophes in Italy (SICI): a tool for managing landslide and flood hazards, Nat. Hazards Earth Syst. Sci., 4, 213-232, doi:10.5194/nhess-4-213-2004, 2004. 
Hungr, O., Evans, S. G., Bovis, M., and Hutchinson, J. N.: Review of the classification of landslides of the flow type, Environ. Eng. Geosci., 7, 221-238, 2001.

Jakob, M. and Hungr, O. (Eds.): Debris Flow Hazards and Related Phenomena, Springer-Praxis Book in Geophysical Science, Springer-Verlag Berlin Heidelberg NY, ISBN 3-540-20726-0, 733 pp., 2005.

Jourde, H., Roesch, A., Guinot, V., and Bailly-Comte, V.: Dynamics and contribution of karst groundwater to surface flow during Mediterranean flood, Environ. Geol., 51, 725-730, 2007.

Larsen, M. C., Wieczorek, G. F., Eaton, L. S., Morgan, B. A., and Torres-Sierra, H.: Natural hazards on alluvial fans; The Venezuela debris flow and flash flood disaster, US Geological Survey, Fact Sheet, 103-01, 2001.

Lionello, P., Bhend, J., Buzzi, A., Della-Marta, P. M., Krichak, S., Jansà, A., Maheras, P., Sanna, A., Trigo, I. F., and Trigo, R.: Cyclones in the Mediterranean region: climatology and effects on the environment, in: Mediterranean Climate Variability, edited by: Lionello, P., Malanotte-Rizzoli, P., Boscolo, R., Elsevier, 325-372, ISBN10-0-444-52170-4, 2006.

Llasat, M. C., Barriendos, M., Barrera, T., and Rigo, T.: Floods in Catalonia (NE Spain) since the 14th century. Climatological and meteorological aspects from historical documentary sources and old instrumental records, J. Hydrol., 313, 32-47, 2005.

Marchi, L. and Tecca, P. R.: Some observations on the use of data from historical documents in debris flow studies, Nat. Hazards, 38, 301-320, 2006.

Morel, C. and Senesi, S.: A climatology of mesoscale convective systems over Europe using satellite infrared imagery. II: Characteristics of European mesoscale convective systems, Q. J. Roy. Meteor. Soc., 128, 1973-1995, 2002.

Orlansky, I.: A rational subdivision of scales for atmospheric processes, B. Am. Meteor. Soc., 56, 527-530, 1975.

Passerini, G.: Intorno alle cause del disastro del marzo 1924 nella Penisola Sorrentina, Boll. Ist. Agrario di Scandicci, Ricerche ed esperienze istituite dal 1914 al 1925, 8, ISBN: 0366-1881, 249269, 1925.

Penta, F., Lupino, R., Camozza, F., and Esu, F.: Effetti dell'alluvione del 26 ottobre 1954 nel Salernitano, Rivista Italiana di Geotecnica, 6, 245-257, 1954.

Perez, F. L.: Matrix granulometry of catastrophic debris flows (December 1999) in central coastal Venezuela, Catena, 45, 163-183, 2001.

Pierson, C.: Hyperconcentrated flow-transitional process between water flow and debris flow, in: Debris-flow Hazards and Related Phenomena, edited by: Jakob, M., and Hungr, O, Springer/Praxis, Chichester, UK, 159-202, 2005.
Plate, J: Flood risk and flood management, Journal of Hydrology, 267, 2-11, 2002.

Porfido S., Esposito E., Alaia F., Molisso F., and Sacchi M.: The use of documentary sources for reconstructing flood chronologies on the Amalfi rocky coast (southern Italy). in: Geohazard in Rocky Coastal Areas, edited by: Violante C., Geological Society of London, Special Publications, 322, 173-187, doi:10.1144/SP322.8, 2009.

Raffel, M., Willert, C. E., Wereley, S. T., and Kompenhans, J.: Particle Image Velocimetry, A Practical Guide, 2nd Ed., Springer Berlin. 447 pp. 2007.

Sacchi, M., Molisso, F., Violante, C., Esposito, E., Insinga, D., Lubritto, C., Porfido, S., and Toth, T.: Insights into flood dominated fan deltas: very high-resolution seismic examples off the Amalfi cliffed coasts, eastern Tyrrhenian Sea, in: Geohazard in Rocky Coastal Areas, edited by: Violante C., Geological Society of London, Special Publications, 322, 33-72, doi:10.1144/ SP322.2, 2009.

Sigurdsson, H., Carey, S., Cornell, W., and Pescatore, T.: The eruption of Vesuvius in AD 79, Nat. Geogr. Res., 1, 332-387, 1985.

Singh, V. P. (Ed.): Hydrologic Systems. Watershed Modelling, Prentice Hall Englewood Cliffs, New Jersey, 320 pp., 1989.

Smith, K. and Ward, L.: Floods. Physical processes and human impacts, Chichester, John Wiley, 382 pp., 1998.

Thunis, P. and Bornstein, R: Hierarchy of Mesoscale Flow Assumptions and Equations, J. of Atmos. Sci., 53, 380-397, 1996.

Tropeano, D. and Turconi, L.: Using historical documents for landslide, debris flow and stream flood prevention, Applications in Northern Italy, Nat. Hazards, 31, 663-679, 2004.

USDA-SCS: Technical Release 55: Urban Hydrology for Small Watersheds, USDA (U.S. Department of Agriculture), http://www. cpesc.org/reference/tr55.pdf, 1986a.

USDA-SCS: National Engineering Handbook, Section 4 - Hydrology, Washington, D.C., 80 pp., 1986 b.

USACE HEC: Hydrologic Modelling System version 3.5, User's Manual (CPD-74A), 306 pp., 2010.

Violante, C.: Rocky coast: geological constrains for hazard assessment, in: Geohazard in Rocky Coastal Areas, edited by: Violante C., Geological Society of London, Special Publications, 322, 131, doi:10.1144/SP322.1, 2009.

Violante, C., Biscarini, C., Esposito, E., Molisso, F., Porfido, S., and Sacchi, M.: The consequences of hydrologic events on steep coastal watersheds: the Costa d'Amalfi, eastern Tyrrhenian Sea, in: The Role of Hydrology in Water Resource Management, edited by: Liebscher, H. J., Clarke, R., Rodda, J., Schultz, G., Schumann, A., Ubertini, L., and Young, G., Capri Italy, 2008. IAHS Publication, 327, 102-113, 2009. 